\title{
Graptoloid evolutionary rates track Ordovician-Silurian global climate change
}

\author{
ROGER A. COOPER*†, PETER M. SADLER $\ddagger$, AXEL MUNNECKE $\& \&$ \\ JAMES S. CRAMPTON* \\ * GNS Science, PO Box 30368 Lower Hutt, New Zealand \\ $\ddagger$ Department of Earth sciences, University of California, Riverside, CA 92521, USA \\ $\S$ GeoZentrum Nordbayern, Fachgruppe Paläoumwelt, University Erlangen-Nuremberg, Loewenichstra $\beta$ e 28 , \\ Erlangen D-91054, Germany
}

(Received 13 September 2012; accepted 31 January 2013; first published online 7 June 2013)

\begin{abstract}
Graptoloid evolutionary dynamics show a marked contrast from the Ordovician to the Silurian. Subdued extinction and origination rates during the Ordovician give way, during the late Katian, to rates that were highly volatile and of higher mean value through the Silurian, reflecting the significantly shorter lifespan of Silurian species. These patterns are revealed in high-resolution rate curves derived from the CONOP (constrained optimization) scaled and calibrated global composite sequence of 2094 graptoloid species. The end-Ordovician mass depletion was driven primarily by an elevated extinction rate which lasted for $c$. 1.2 Ma with two main spikes during the Hirnantian. The early Silurian recovery, although initiated by a peak in origination rate, was maintained by a complex interplay of origination and extinction rates, with both rates rising and falling sharply. The global $\delta^{13} \mathrm{C}$ curve echoes the graptoloid evolutionary rates pattern; the prominent and well-known positive isotope excursions during the Late Ordovician and Silurian lie on or close to times of sharp decline in graptoloid species richness, commonly associated with extinction rate spikes. The graptoloid and isotope data point to a relatively steady marine environment in the Ordovician with mainly background extinction rates, changing during the Katian to a more volatile climatic regime that prevailed through the Silurian, with several sharp extinction episodes triggered by environmental crises. The correlation of graptoloid species diversity with isotopic ratios was positive in the Ordovician and negative in the Silurian, suggesting different causal linkages. Throughout the history of the graptoloid clade all major depletions in species richness except for one were caused by elevated extinction rate rather than decreased origination rate.
\end{abstract}

Keywords: climatic forcing, diversity, extinction, plankton.

\section{Introduction}

The Silurian is a period of marked instability in marine environmental conditions (Calner, 2008; Munnecke et al. 2010). A long interval of relatively stable greenhouse conditions through the Early and Middle Ordovician, with nitrogen-limited ecosystems and widespread anoxia, contrasts with the icehouse conditions that prevailed through much of the later part of the Ordovician and the Silurian: ventilated, phosphorus-limited oceans, extreme positive $\delta^{13} \mathrm{C}$ excursions, a fluctuating strongly zoned climate and periodic growth of continental ice sheets (Samtleben et al. 1996; Saltzman, 2005; Saltzman \& Young, 2005; Díaz-Martínez \& Grahn, 2007; Calner, 2008; Trotter et al. 2008; Vandenbroucke et al. 2010; Sadler \& Cooper, 2011; Zhang et al. 2011; Cramer et al. 2012). Sedimentological, geochemical, isotopic and biological proxies point to a major transition during the Late Ordovician in mean surface water temperature, redox, circulation and density stratification and carbon sequestration patterns (e.g. Saltzman, 2005; Finnegan et al. 2011; Zhang et al. 2011). In the Cenozoic oceans,

$\dagger$ Author for correspondence: r.cooper@gns.cri.nz planktic microfossils provide sensitive indicators of such changes in the marine realm (e.g. Hayward et al. 2012; Peters et al. 2013); in the Early Palaeozoic, graptoloids (planktic graptolites) have the potential to fulfil the same role. The graptoloid clade conveniently spans the Ordovician and Silurian periods, which include the Great Ordovician Biodiversification Event (GOBE; Sepkoski, 1995; Webby et al. 2004; Servais et al. 2010), one of the five great mass extinctions (end-Ordovician mass extinction; Sheehan, 2001; Bambach et al. 2004), and the early Silurian recovery (Melchin et al. 2011).

So far, most attempts to detect global environmental change in the Palaeozoic Era using fossil proxies have been limited to the time resolution of biostratigraphic zonal schemes of groups such as conodonts or graptolites (0.5-1.5 Ma). Individual sections can yield high-resolution records of faunal change but through only short periods and for only local regions (e.g. Finney et al. 1999; Vecoli et al. 2009). Integrated biostratigraphy and isotope stratigraphy can yield high temporal resolution for parts of the timescale (Cramer et al. 2010; Bergström et al. 2012). We use the CONOP (constrained optimization) method (Sadler, 2004) to composite the graptoloid species ranges from many 
local range charts into a single global best-fit composite sequence spanning the entire lifespan of the clade (base Ordovician to Lochkovian), which can be scaled and calibrated to give a high-resolution timescale (Sadler et al. 2009). Using the protocols and run parameters adopted for the present study (see Sadler et al. 2011), the CONOP method searches for the global first and last appearance (FA and LA, respectively) events for each taxon, thereby reducing the effect of incompleteness in local sections or regions. Imprecision in estimating the age and duration of zones or other time intervals is avoided because the species' first and last appearance event levels in the CONOP graptolite composite are calibrated directly by regression against the 22 radiometric dates used for calibrating the Ordovician and Silurian timescales (Sadler et al. 2009; Cooper \& Sadler, 2012; Melchin et al. 2012), and not via zones.

Because graptoloids were a planktic group with relatively short-ranging species of wide geographic distribution, they have been used extensively for biostratigraphic dating and correlation and their stratigraphic ranges are well recorded in measured sections in the literature.

A phylogenetic analysis of some key Late Ordovician and early Silurian graptoloids (Melchin et al. 2011) has provided a firmer phylogenetic framework for understanding the evolution and classification of graptoloids in this interval of profound change in graptoloid diversity, composition and faunal turnover. Here we adopt the nomenclature of Melchin et al. (2011) for the Neograptina. Ordovician graptoloid classification follows Mitchell et al. (2007), Maletz et al. (2009) and Sadler et al. (2011).

\section{Methods and data}

The CONOP graptolite database used for this study contains the stratigraphic ranges of 2046 graptoloid species in 518 sections that collectively span the lifespan of the graptoloid clade. The sections and faunal lists used have been compiled from the literature and screened for taxonomic and biostratigraphic reliability as explained by Sadler et al. (2009, 2011), who also discuss the completeness of geographic and stratigraphic coverage. A total of $43 \%$ of the species are found in no more than one section and, although they are a valid part of the measures of species richness, do not assist in the correlation procedure. The global composite sequence is that used for construction of the Ordovician and Silurian geochronological scales (Cooper \& Sadler, 2012; Melchin et al. 2012) and has been built, scaled and calibrated using the method described by Sadler et al. (2009) with the refinements of Sadler et al. (2011). These refinements include greatly increasing the weight of taxa known from five or more sections during the compositing procedure, thus ensuring that the stratigraphically best-controlled and best-sampled sections have the greatest influence in the composite. The density and overlap in ranges of the sections is such that (except for the very basal
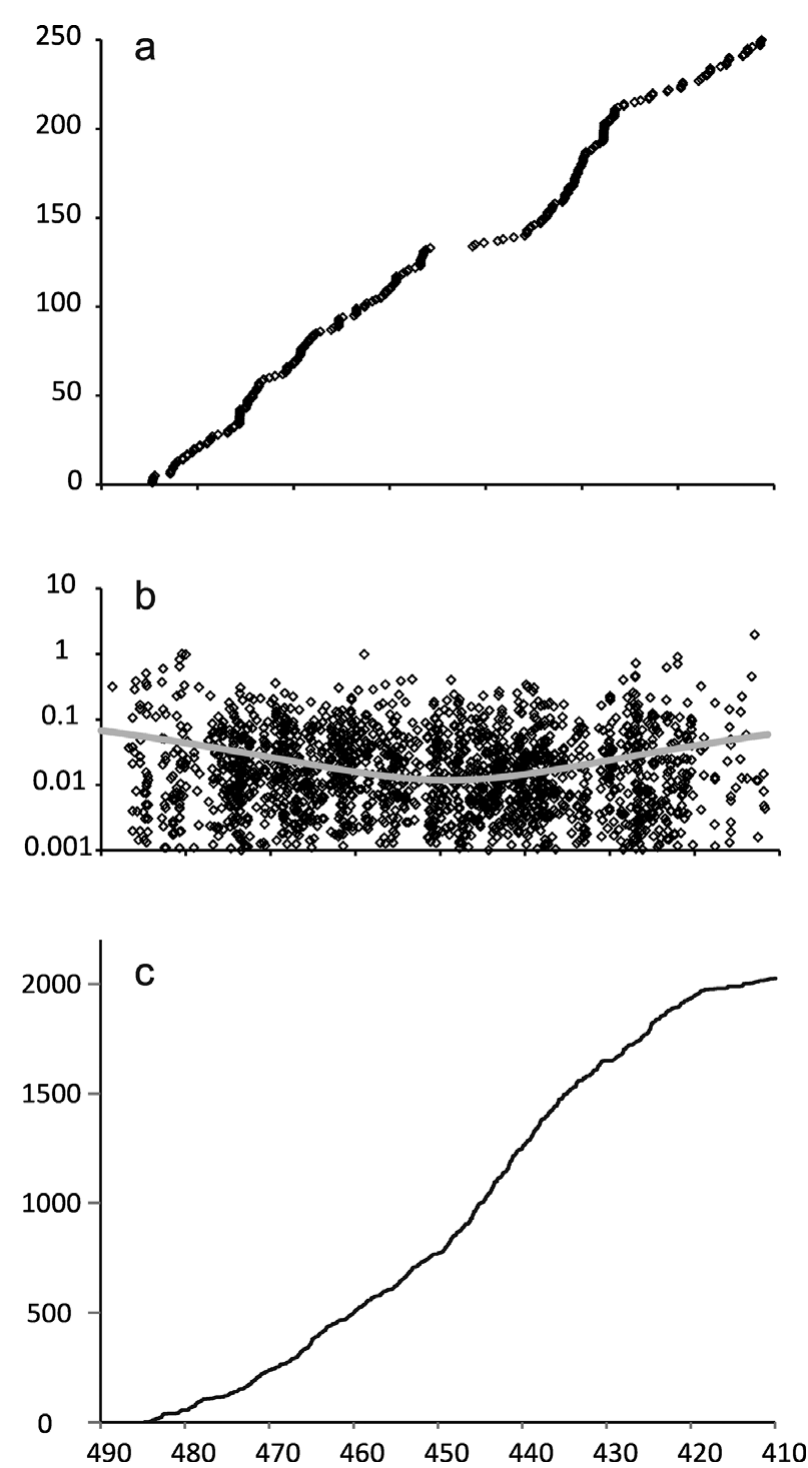

Figure 1. Qualities of the high-resolution graptoloid time line. (a) Age distribution of 244 species with a stratigraphic range of $0 \mathrm{~m}$ in our composite. These are mainly species recorded at a single level in a single section. $Y$-axis is cumulative frequency. (b) Spacing of levels in the composite sequence from base Ordovician to Early Devonian. $Y$-axis is spacing between adjacent levels in Ma, logarithmic scale; regression line is a second-order polynomial. Resolution is lowest near the base and top of the clade (below $475 \mathrm{Ma}$ and above $425 \mathrm{Ma}$ ). (c) Cumulative frequency of event level spacing in the composite. $Y$-axis shows event levels in composite order (i.e. not scaled in time). Curve is steepest where event levels are most closely spaced. $X$-axis: Ma (486-411 Ma).

portion) every event level in the composite is spanned by at least 10 , and up to 80 , sections with an average of over 50 (Sadler et al. 2011).

For the estimates of evolutionary rates, we have removed from our dataset 244 species that have a stratigraphic range of $0 \mathrm{~m}$ in our scaled composite. These are mostly species found at a single level in a single section and are those most likely to be severely under-sampled. These species have been included in the richness counts, however. They are well scattered through the composite (Fig. 1a) and their removal has little effect on the richness and rate curves. 

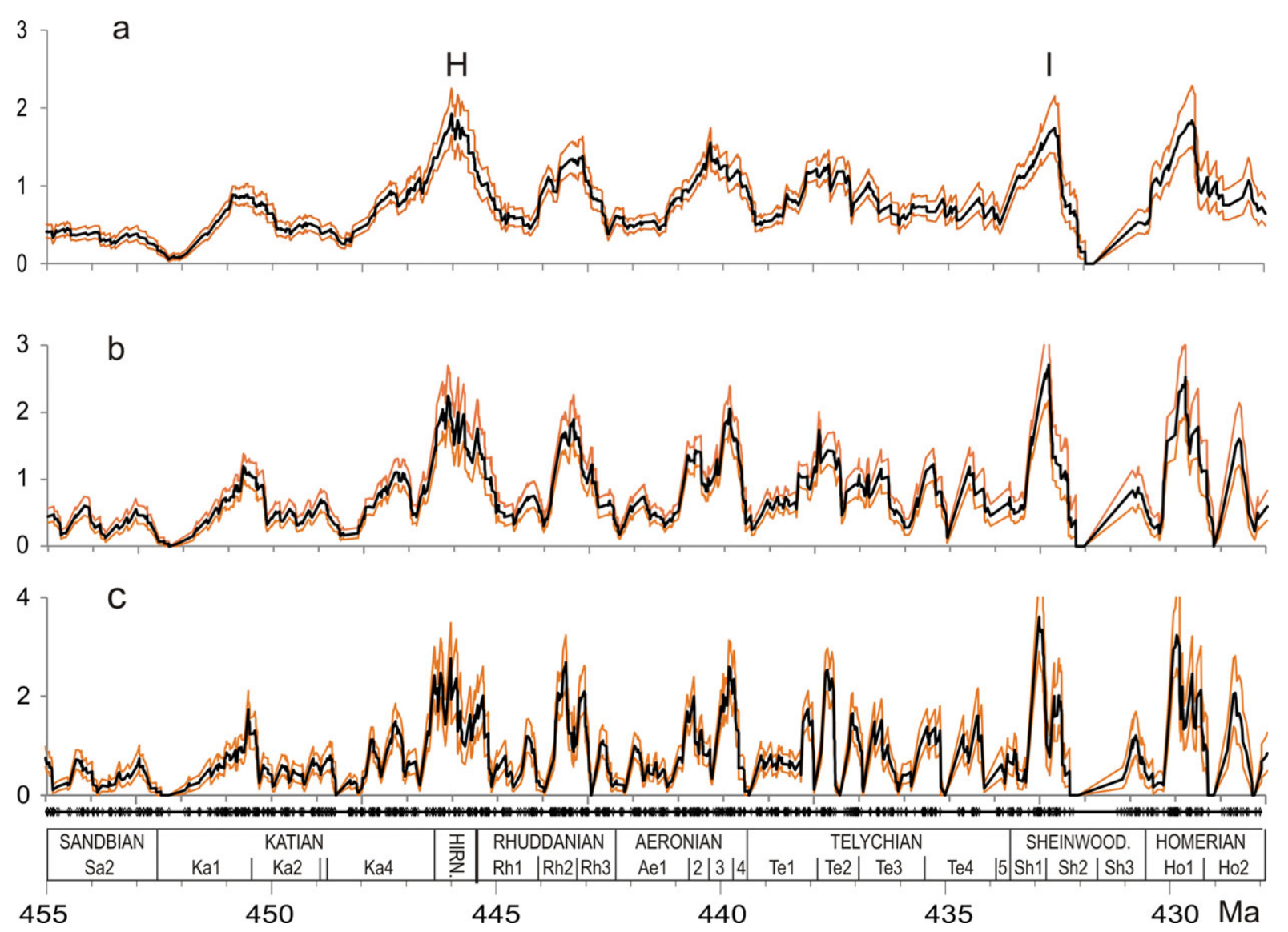

Figure 2. (Colour online) Extinction rate curve ( $q$, extinctions per Lmy, $y$-axis) from 428 Ma to 455 Ma, Late Ordovician - early Silurian, with $\pm 1 \sigma$ uncertainty limits derived by bootstrapping the data 500 times. The curve is shown in three levels of resolution, all with a centred moving window: (a) $1 \mathrm{Ma}$ window; (b) $0.5 \mathrm{Ma}$ window; and (c) $0.25 \mathrm{Ma}$ window. Several of the rate peaks in (a) decompose to multiple peaks in (b) and (c) that are significantly distinct $(p<0.05)$. The extensively studied extinction events in the Katian-Hirnantian and Sheinwoodian are marked 'H' and ' $I$ ', respectively. Also shown, below (c), is the location of composite levels with extinction events.

This leaves 1802 graptoloid species for the analysis, giving 3604 range-end events and a composite with 2031 steps (event levels or 'sample points'). There is therefore an average of 1.78 events per level, equivalent to 48 events ( 24 origination events and 24 extinction events) per Ma. The 2031 levels span $74 \mathrm{Ma}$, so are spaced $37 \mathrm{ka}$ apart on average. This is the limiting resolution of our rates and richness curves. Spacing between levels is widest at the top and bottom of the composite sequence, where species richness is lowest (Fig. 1b, c).

Uncertainty limits on the rate curves have been derived by bootstrapping the data, using species as the units of resampling, with 500 bootstrap iterations at each level of the composite. The bootstrap mean value is plotted (which differs insignificantly from the bootstrap median or from the mean based on the observed values) and $\pm 1 \sigma$ from the mean (Fig. 2). This enables a peak to be distinguished from an adjacent trough at two standard deviations, which approximates the $0.05 p$-value.

For cross-correlation of the graptolite evolutionary rates, diversification and richness data with the carbon isotope curve, it is necessary to first place the two suites of data on a common timescale. To achieve this, we calculated the graptoliod rate and diversity measures for uniform time bins of $0.1,0.25$ and $0.5 \mathrm{Ma}$. For the carbon isotope data, digitized from the hand-drawn curves of Bergström et al. (2009) and Cramer et al. (2011), we used linear interpolation at closely spaced intervals $(0.01 \mathrm{Ma})$ to create uniformly spaced points, and then averaged these points within the same time bins that were used for the graptolite data. The resultant curves closely match the original digitized carbon isotope curve. Cross-correlations are sensitive to small variations in starting points of the uniform time bins (i.e. variations of less than one bin duration). This sensitivity reflects uncertainties in the time series that are captured by bootstrapping. The reported cross-correlations are therefore based on bootstrap means of the graptolite data, using the approach described above and the uniform time bins instead of individual levels in the composite. Further, we only discuss cross-correlations that are robust to variations in both offset and duration of the time bins. Correlations reported below are for the $0.25 \mathrm{Ma}$ bins, although conclusions do not change if other bin durations are used. All correlations are based on data that have been detrended using first differences. 
Table 1. Timescale (Cooper \& Sadler, 2012; Melchin et al. 2012)

\begin{tabular}{|c|c|c|c|}
\hline & $\begin{array}{l}\text { Stage lower } \\
\text { boundary }\end{array}$ & $\begin{array}{l}\text { Spline age } \\
(\mathrm{Ma})\end{array}$ & $\begin{array}{c}\text { Polynomial age } \\
\text { (Ma) }\end{array}$ \\
\hline \multirow{9}{*}{$\frac{\stackrel{\Xi}{\Xi}}{\stackrel{\Xi}{\Xi}}$} & Base Devonian & 419.20 & 417.64 \\
\hline & Pridolian & 422.96 & 422.39 \\
\hline & Ludfordian & 425.57 & 425.32 \\
\hline & Gorstian & 427.36 & 427.24 \\
\hline & Homerian & 430.45 & 430.54 \\
\hline & Sheinwoodian & 433.35 & 433.60 \\
\hline & Telychian & 438.49 & 439.42 \\
\hline & Aeronian & 440.77 & 442.33 \\
\hline & Rhuddanian & 443.83 & 445.33 \\
\hline \multirow{7}{*}{$\frac{\frac{\pi}{0}}{\frac{0}{0}}$} & Hirnantian & 445.16 & 446.44 \\
\hline & Katian & 452.97 & 452.61 \\
\hline & Sandbian & 458.36 & 457.68 \\
\hline & Darriwilian & 467.25 & 467.69 \\
\hline & Dapingian & 469.96 & 470.82 \\
\hline & Floian & 477.72 & 479.03 \\
\hline & Tremadocian & 485.37 & 485.91 \\
\hline
\end{tabular}

NB Polynomial age is used here

Bootstrap analyses, calculation of uniform bin data, resampling of the isotope curve and cross-correlation analyses were performed using $\mathrm{R}$ (R Development Core Team, 2011).

The timescale used here is based on the same sets of graptolite biostratigraphic data and radiometric data as those used for construction and calibration of the global Ordovician and Silurian timescales (Melchin et al. 2012; Cooper \& Sadler, 2012). The calibration that we use is based on a polynomial fit of the radiometrically dated bentonite samples to the CONOP composite levels for those samples, as explained by Sadler et al. (2009), rather than a cubic spline fit of the data favoured by Gradstein et al. (2012). The two calibrations are similar (Table 1; both are given in Gradstein et al. 2012), but differ at the top and bottom of the interval studied (Lochkovian, Pridoli and Tremadocian) and near the Ordovician-Silurian boundary. The difference in calibration has no material effect on the rates discussed here. The most appropriate curve-fitting method is ultimately a matter of opinion, but here we prefer the polynomial method because of its convenience for precisely calibrating all 2031 levels in the composite via the polynomial function (Sadler et al. 2009).

\section{Macroevolutionary rate metrics}

A running curve of standing richness through the entire $74 \mathrm{Ma}$ of the graptoloid clade is readily derived from the scaled and calibrated composite sequence which is, in effect, a global biostratigraphic range chart of 2046 species. The composite levels of FA and LA events (range-end events) are equivalent to sampling levels for taxon range ends in a highly resolved stratigraphic section. Because levels in the CONOP calibrated composite are spaced only $37 \mathrm{ka}$ apart on average and there are, on average, only 1.78 range-end events per level, we have a record of graptoloid species ranges with an exceptionally high temporal resolution.
Assuming that the recorded FA and LA events represent species origination and extinctions events, we can regard the record as a literal one in which there is no significant species turnover between levels. Clearly we cannot deny the possibility that a species' true first appearance did not occur up to $37 \mathrm{ka}$ earlier than we have recorded it, and that no regional biostratigraphic section has detected it; such possibilities will make no significant difference to our recorded originations and extinctions through time, however. We can therefore regard all species recorded at any level as boundarycrossers (sensu Foote, 2000). This approach avoids the troublesome biases introduced by time-binning the data (Foote, 1994, 2000; Foote \& Miller, 2007; Alroy, 2010). Although the species richness curve shown here (Figs 3, 4) is a raw ('as-measured') curve, Sadler et al. (2011) have shown that the main topographic features of the curve are robust to a variety of tests for sampling completeness. The main features survive rarefaction even at low levels of resampling (50 or 100 samples).

Unlike taxon richness, origination and extinction rates are inherently time-binned concepts. We must determine these rates as within-bin averages with consequent loss of resolution; because the age distribution of evolutionary events within the bin is known in high resolution, there is no need to estimate it. Accordingly, we report the rate data in $1 \mathrm{Ma}$ bins, or shorter-duration bins for higher resolution $(0.5 \mathrm{Ma}, 0.25 \mathrm{Ma})$ and we have the freedom to use a sliding bin, centred at each of the 2031successive event levels in the composite. The rate is therefore recalculated at every level producing, in effect, an instantaneous rate curve and a means to scan the data for the most precise placement of turning points in the rate curves. The instantaneous per-capita rates for origination $(p)$, extinction $(q)$ and turnover $(p+q)$ are scaled to lineage length, normally expressed as per lineage million years (Lmy) following Raup (1985) and Foote \& Miller (2007). The number of extinctions $N(\mathrm{e})$ or originations $N(\mathrm{o})$ in any time interval $t$ is divided by the sum of all lineage segments that lie within the interval, in millions of years. Lmy thus relates an extinction (or origination) event to the aggregate time during which all lineages were exposed to extinction (or speciation) within the interval. For the extinction rate in time interval $t: q_{t}=N(\mathrm{e})_{t} /(\mathrm{Lmy})_{t}$. Similarly, for origination rate in time interval $t: p_{t}=$ $N(\mathrm{o})_{t} /(\mathrm{Lmy})_{t}$. Species turnover rate is simply $q_{t}+p_{t}$.

The results are plotted against the $\delta^{13} \mathrm{C}_{\text {carb }}$ data summarized in Bergström et al. (2009) for the Ordovician and in Cramer et al. (2011) for the Silurian (Figs 3, 4). Numerous studies have proven $\delta^{13} \mathrm{C}_{\text {carb }}$ to be a reliable chemostratigraphic proxy. In contrast, the carbon isotopic composition of organic matter $\delta^{13} \mathrm{C}_{\text {org }}$ depends on a variety of factors such as light intensity, $p \mathrm{H}$ of ambient seawater, organism cell geometry, heterotrophic reworking, metabolic effects and species composition of the phytoplankton community (Hinga et al. 1994; Hayes et al. 1999; Bickert, 2006); it therefore often exhibits more 'noise' 


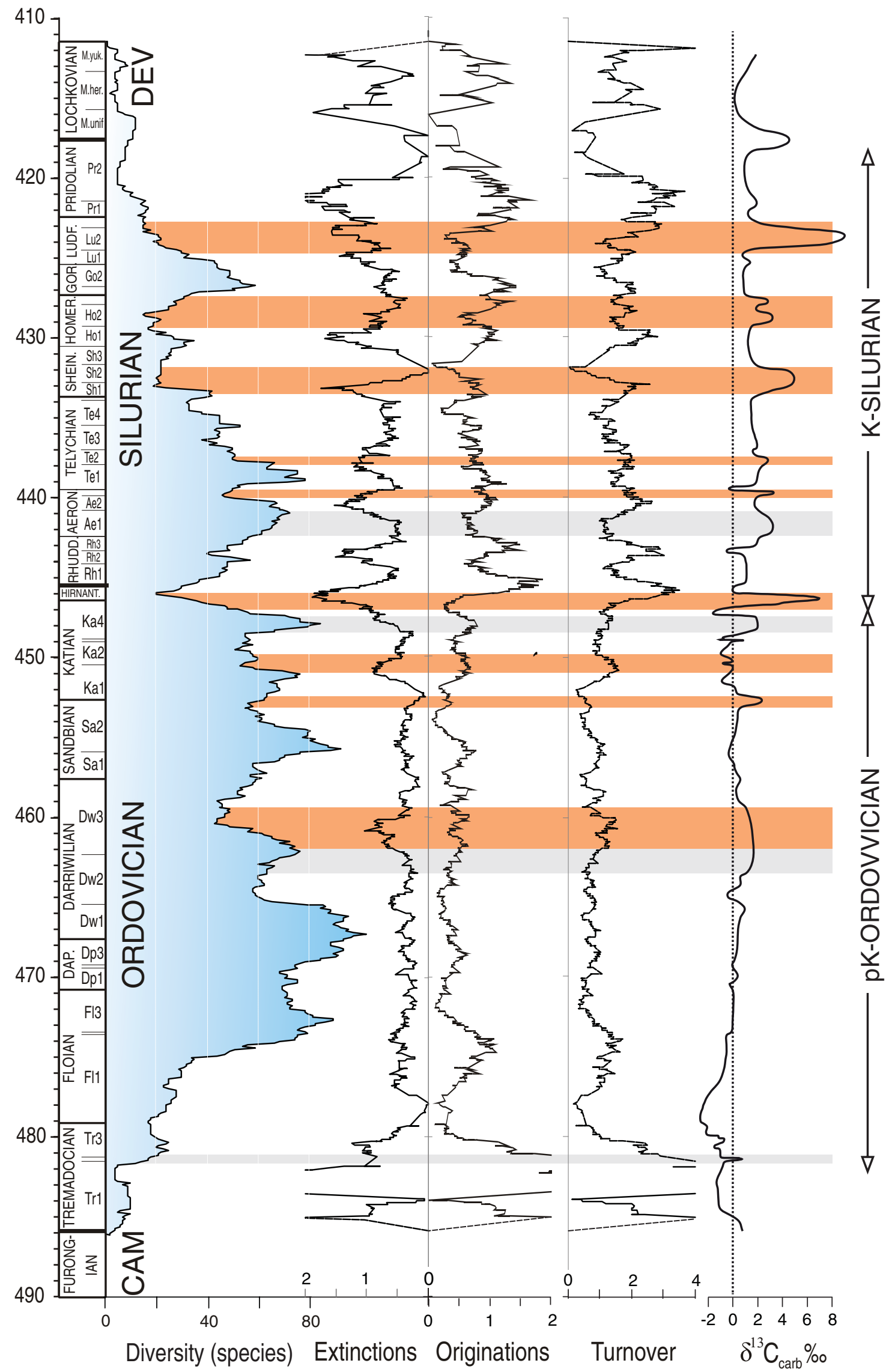

Figure 3. (Colour online) Per capita instantaneous extinction $q$, origination $p$ and turnover $p+q$ rate curves (species per Lmy, $1 \mathrm{Ma}$ smoothing) and species richness (unbinned) for the entire graptoloid clade. $\delta^{13} \mathrm{C}$ (carbonate) curves and stage slices are from Cramer et al. (2011) and Bergström et al. (2009) and are correlated via graptolite and conodont zones. Positive isotope excursions associated with extinction rate peaks and/or low or falling richness are in darker-shaded bands; those with rising or peak richness are in lighter-shaded bands. 


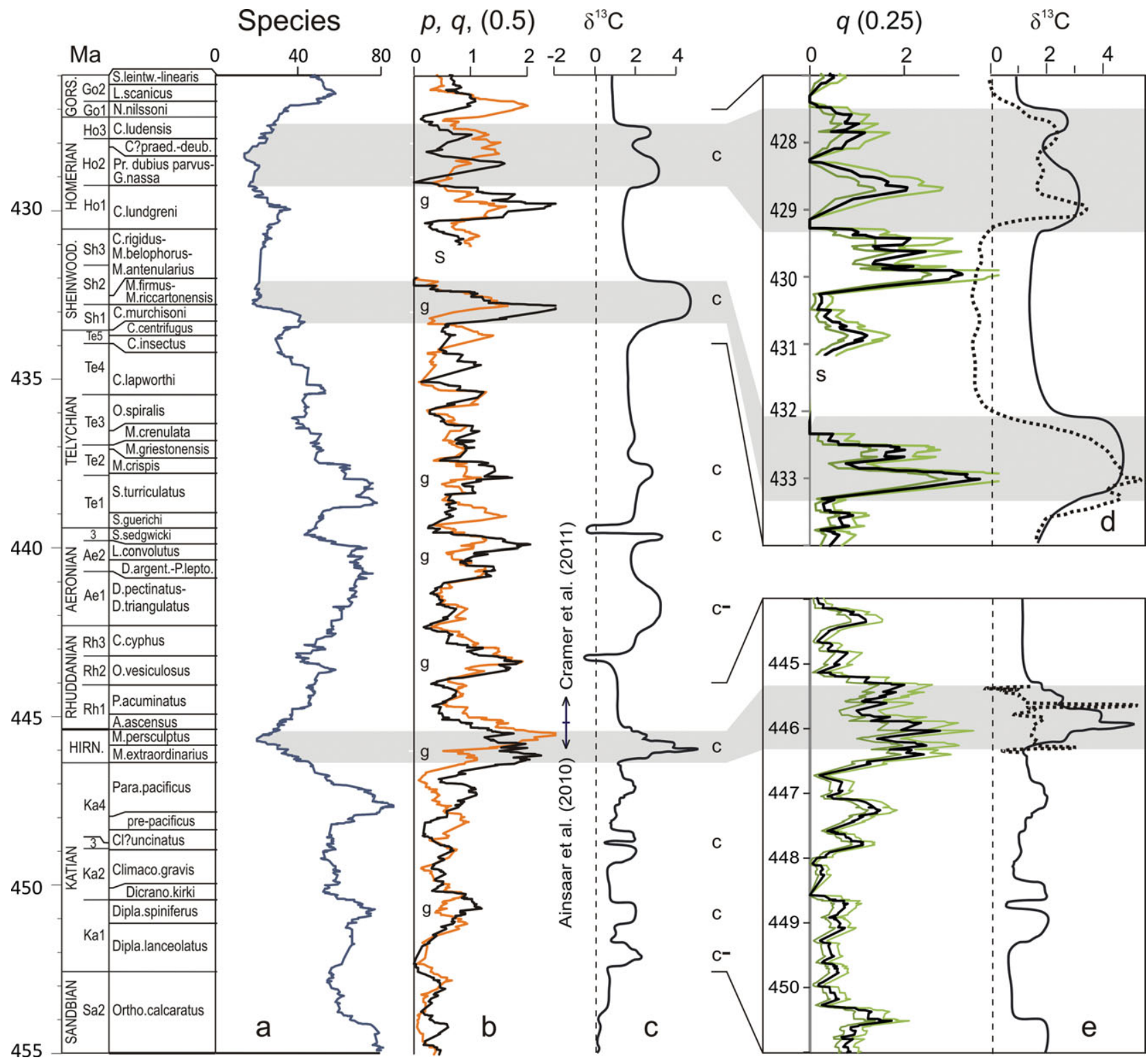

Figure 4. (Colour online) Late Ordovician - Middle Silurian interval spanning the end-Ordovician mass extinction, Llandovery recovery and two of the Silurian major carbon isotope excursions. (a) Unbinned species richness (Sadler et al. 2011). (b) Per capita instantaneous extinction rate $(q$, black line) and origination rate ( $p$, grey line) with a sliding $0.5 \mathrm{Ma}$ bin for rate determination. Evolutionary rates are expressed as per Lmy rates. (c) $\delta^{13} \mathrm{C}_{\text {carb }} \%$ o from Ainsaar et al. (2010) and Cramer et al. (2011). (d) Inset enlargement with the Sheinwoodian and Homerian isotope excursions (shaded) and the extinction rate in higher resolution ( 0.25 Ma sliding bin); $\pm 1 \sigma$ limits shown. Dotted line: $\delta^{13} \mathrm{C}$ curve reconstructed from unaltered brachiopod shell calcite from the Silurian of Gotland (compiled after Samtleben et al. 1996, 2000; Munnecke et al. 2003; Cramer et al. 2010). (e) Same as (d) for the late Katian and Hirnantian excursions and extinction rate curve. Dotted line: whole-rock $\delta^{13} \mathrm{C}$ curve from the Hirnantian of Mirni Creek (NE Russia). The peak of the HICE plots well within the persculptus zone (Kaljo \& Martma, 2011). g - graptolite extinction event; c, $\mathrm{c}^{-}-$carbon isotope event; $\mathrm{S}-$ insufficient resolution.

than contemporaneous $\delta^{13} \mathrm{C}_{\text {carb }}$ curves (e.g. Cramer \& Saltzman 2007). Furthermore, there is much less published $\delta^{13} \mathrm{C}_{\text {org }}$ data than for $\delta^{13} \mathrm{C}_{\text {carb }}$.

\section{Graptoloid evolutionary rate dynamics}

The rates and species richness curves are plotted alongside the generalized global $\delta^{13} \mathrm{C}$ curve in Figure 3 . Graptoloid species richness is estimated from our species list of 2094 species, the best-supported graptoloid richness estimate yet published (Sadler et al. 2011). The impact of an extinction event depends on both the intensity of the event (the per Lmy rate) and the duration of the event; impact therefore depends on the area under the curve. Note that richness falls when the extinction rate $q$ is greater than the origination rate $p$, whether or not one or both rates are increasing, decreasing or remaining stationary. The converse holds for richness increase.

It can be seen from Figure 3 that graptoloid evolutionary rates through most of the Ordovician were 
relatively low and of low amplitude compared with the Silurian, during which rates were higher and more volatile. The transition from one state to the other takes place not at the period boundary but in the Katian Stage. In higher resolution (Fig. 4), the extinction rate can be seen to change between $c .446 .5 \mathrm{Ma}$ and $451 \mathrm{Ma}$ but the origination and turnover rates change at c. $447 \mathrm{Ma}$. If we ignore the extreme rates values at the beginning (Tremadocian) and end (Lochkovian) of the clade where richness is very low (fewer than 10 species), and take the boundary between an Ordovician pattern and a Silurian pattern at $447 \mathrm{Ma}$, we can contrast the evolutionary dynamics of the two periods. For convenience we refer to that part of the Ordovician prior to the late Katian as $p K$-Ordovician, and to the late Katian to end Silurian as $K$-Silurian.

Mean species turnover rate for the K-Silurian $(1.66 / \mathrm{Lmy})$ is twice that for the pK-Ordovician $(0.86 / \mathrm{Lmy})$ and this contrast is reflected in the extinction and origination rates from which the turnover rate is derived. The tempo of graptoloid evolution in the $\mathrm{K}-$ Silurian is therefore significantly higher than in the $\mathrm{pK}$ Ordovician. The median duration of a pK-Ordovician species is $1.27 \mathrm{Ma}$, significantly greater than that of a K-Silurian species (0.69 Ma; Mann Whitney-U $p$ $<0.001$ ), reflecting the higher turnover rates. Not only is the mean intensity of evolutionary turnover higher in the K-Silurian, it fluctuates more strongly. During the pK-Ordovician, rate curve excursions were of much lower amplitude $(\sigma=0.72$ for the K-Silurian and 0.33 for the $\mathrm{pK}$-Ordovician; $p<0.001 ; d f=1$ ).

Near the beginning and end of the graptoloid clade, where species richness is very low (10 species or less), the loss (or addition) of just a few species results in extreme values in the proportional rate curves. One of these extremes in the Tremadocian (Tr1) nearly extinguished the clade altogether which, at that time, was represented only by the stem group Anisograptidae; richness dropped to 2 or 3 species in our dataset.

A sustained period of moderately elevated origination rate in the Floian (F11, early Bendigonian) produced a rapid increase in species richness of the clade (Floian radiation), which was maintained at 40 100 species throughout the remaining Ordovician. The expansion phase of the Graptoloidea (486-473 Ma) was exponential rather than logarithmic or linear $\left(R^{2}=0.8672, R^{2}=0.7962\right.$ and $R^{2}=0.7941$, respectively) and continued until near-peak richness levels were reached, indicating an adaptive radiation of the clade. The increase was driven by the expansion of the 'Dichograptidae' (didymograptids, Tetragrapta) and Sinograpta (includes sigmagraptids). Speculating on the driving mechanisms, Sadler et al. (2011) pointed out that the expansion does not seem to have been triggered by breaking through a functional threshold or an evolutionary innovation such as new body plans, thecal types, feeding mechanisms, rhabdosome designs or proximal development types. Rather, there was a proliferation of species using the available designs, for example pendent and extensiform didymograptids, phyllograptid designs and horizontal dichotomous, progressive and monoprogressive branching types. Although some genera such as Expansograptus (which proliferated in this interval) undoubtedly need rationalizing to remove species based on morphotypes rather than populations, it is unlikely that the observed pattern of expansion could be entirely, or even largely, explained by this. Work in progress by the authors indicates that the Ordovician expansion in species richness of graptoloids was facilitated not only by a sustained and moderately elevated origination rate but by an increase in median longevity of species that was maintained through the $\mathrm{pK}$-Ordovician at a level twice that of the Silurian (see Section 7). It was also facilitated by the extinction rate remaining at background levels.

Many marine invertebrate groups radiated during the Early and Middle Ordovician during the Great Ordovician Biodiversification Event (Webby et al. 2004) and it is likely that, in large part, the graptolites responded to stimuli that were global in extent and pantaxonomic in their influence. Among these is likely to have been the availability of trophic resources. The marine microphytoplankton, as represented by the acritarchs, diversified through the Late Cambrian and Early Ordovician, peaking in the Darriwilian ( $\mathrm{Li}$ et al. 2007; Servais et al. 2008, 2010), suggesting an expanding food resource for the graptoloids (Rigby, 1991; Cooper et al. 2012). The microphytoplankton and bacterioplankton proliferate when nutrient levels rise such as by nutrient transfer, a modern analogue for which is found in upwelling zones (Finney \& Berry, 1997; Cooper et al. 2012). The expansion of the graptoloids is therefore likely to be linked to extrinsic factors such as ocean circulation, biogeochemistry and, ultimately, to global climatic regime.

Prior to the Katian, the main evolutionary event was the Darriwilian Dw3 extinction and richness minimum, during which the Dichograptidae were severely reduced in species numbers and the isograptids and Sinograpta were terminated. The event was preceded in the late Dw1 - early Dw2 by a smaller extinction event which depleted the standing species richness by c. $30 \%$. During the Darriwilian the Diplograptina, represented by the family-level groups Climacograptoidea and Diplograptidae, became established globally and, together with the Dicranograptoidea and Lasiograptidae, dominated graptolite communities during the Late Ordovician. There was therefore a major re-organization of the graptoloid clade during the Darriwilian, strongly assisted by the Darriwilian extinction event. A substantial extinction event at the Katian Ka1-Ka2 boundary was largely offset by elevated origination rate and had relatively little impact on species richness, but coincides with the demise of the Glossograpta. The extirpation of normalograptids from the Laurentian tropics at this time was followed, during the late Katian and Hirnantian, by their re-invasion and dramatic expansion when they replaced the diplograptines (Goldman et al. 2011). The 
Ka1-Ka2 extinction event may represent a second significant pK-Ordovician event, or was possibly a precursor to the K-Silurian pattern.

With the exception of the Darriwilian and Katian extinction events, the pK-Ordovician pattern suggests that background rates of extinction and turnover prevailed; the K-Silurian pattern of a highly volatile evolutionary dynamic with recurring sharp spikes in the extinction and origination rates however suggests sharp environmental perturbations. Following the KatianHirnantian mass extinction (discussed in Section 6), at least six pronounced graptoloid extinction events punctuate the Silurian. Most have been previously recognized (e.g. by Urbanek, 1993; Štorch, 1995; Melchin et al. 1998; Loydell, 2007) although our zonal assignment of some of the events differs slightly from that previously reported, mainly because of the different method of zone boundary recognition used here (see discussion in Sadler et al. 2009).

The Rhuddanian (Rh2-3) extinction event, Cystograptus vesiculosus to Coronograptus cyphus zones, was first recognized by Melchin et al. (1998) and referred to as the 'Late Parakidograptus acuminatus event'. The extinction affected the Normalograptidae, Dimorphograptidae and Neodiplograptidae. The extinction peak was almost entirely offset by a coincident origination rate peak resulting in a high species turnover, noted by Melchin et al. (1998, 2011), and had little impact on overall species richness. The event triggered a diversification within the Monograptidae and Dimorphograptidae clades (Koren' \& Bjerreskov, 1999).

An Aeronian (Ae2-3) extinction event in the $D$. argenteus to $S$. sedgwicki zones corresponds to the L. convolutus and S. sedgwicki event of Melchin et al. (1998) and Štorch (1995) although our data suggest that, in a global context, it may have started somewhat earlier than generally recognized. The event resulted in a severe but brief drop in species richness in the sedgwicki zone. Retiolitids, including the Petalolithinae, and Monograptidae all declined in species richness. 'Stressed' marine environmental conditions are inferred by Štorch \& Frýda (2012).

In the early Telychian (Te1-2) late $S$. turriculatus and M. crispus zones, Loydell (1994) and Štorch (1995) recognized the Utilis Event. This event, of moderate intensity, is significant in that it marks the beginning of a long decline in global species richness. The spike in origination rate in the guerichi zone accords with previous work, but the high levels of species richness through the turriculatus zone is at variance with some regional studies (Loydell, 1994; Storch, 1994). Biserial graptoloids were nearly eliminated, with a few survivors among the retiolitids, normalograptids and petalolithids (Štorch, 1995).

An extinction event recognized in the Cyrtograptus lapworthi zone of Bohemia (Štorch, 1995), Wales (Loydell, 2007) and Arctic Canada (Melchin, 1998) shows only as a small spike in the extinction rate in our global data. However, there is a marked depletion in species richness in the late $C$. lapworthi and $C$. insectus zones.

The early Sheinwoodian (Sh1) extinction event, $C y r$ tograptus murchisoni to early M. riccartonensis zones, is a widely recognized event (Koren', 1987; Kaljo et al. 1995; Storch, 1995; Melchin et al. 1998; Loydell, 2007) of an intensity exceeding that of the Hirnantian Stage (Fig. 2). Global species richness dropped sharply by $50 \%$ to 20 species, matching the Hirnantian minimum. Many lineages were terminated (Štorch, 1995) including Barrandeograptus, Mediograptus and the Cyrtograptus murchisoni group. According to the correlations of Loydell et al. (2003) and Loydell (2007), the well-known Ireviken conodont extinction event in Gotland (Jeppsson, 1997) coincides with this graptolite event. Some species such as Monoclimacis vomerina group and Monograptus priodon were exterminated from one or more regions only to reappear several zones later (Lazarus taxa; Štorch, 1995). These local extermination events contribute to some regional extinction counts but are not recorded as extinction events in our composite sequence.

In the early Homerian (Ho1), Cyrtograptus lundgreni zone, the 'Große Krise' of Jaeger (1991) has been recognized by many others (Koren', 1991; Lenz, 1993; Štorch, 1995; Gutiérrez-Marco et al. 1996; Melchin et al. 1998; Lenz \& Kozlowska-Dawidziuk, 2001; Loydell, 2007) as a major extinction event. Species richness was reduced to its lowest level since the Floian. The event was immediately followed by two, smaller peaks in extinction rate during the late Homerian (Ho2-3; Fig. 4d). The plectograptines and species of the Pristiograptus dubius group were among the few to have survived; these and other lineages including Gothograptus, Saetograptus and graptolites with peculiar apertural modifications, the cucullograptids, then speciated rapidly, generating an exponential rise to a short-lived peak in global richness and a final 'fling' for the graptoloids.

During the late Ludfordian to early Pridoli an extended and multi-peaked extinction episode almost terminated the only remaining group, the superfamily Monograptoidea. It was accompanied by a sustained elevated origination rate and, as a consequence, a high species turnover rate. Three main extinction events of successively increasing intensity correspond, in upward sequence, to the Saetograptus leintwardensis, Neocucullograptus kozlowskii and Monograptus transgrediens zones. All three were recognized in the sections of Bohemia and eastern Europe (Urbanek, 1993; Štorch, 1995). The first event terminated the plectograptines, the second terminated several genera including Neocucullograptus, Bohemograptus and Polonograptus (Manda et al. 2012) and the third event removed Pseudomonoclimacis, Pristiograptus and all other species of Monograptus s.l. (Koren', 1993; Urbanek, 1993). Global species richness dropped to just 4 species and did not rise above 10 species for the following $9 \mathrm{Ma}$, after which the Graptoloidea disappeared completely. 
It is emphasized that these extinction events and the species richness pattern are global in scope and may differ from the extinction and richness history of local regions. At higher resolution $(0.5 \mathrm{Ma}$ and $0.25 \mathrm{Ma}$ sliding windows, Figs 2,4) several of the extinction rate spikes, including that of the late KatianHirnantian, are seen to comprise multiple peaks which are significantly different at the 0.05 level. Throughout the history of the graptoloid clade, all major depletions in richness except for one were caused by elevated extinction rates (Fig. 3). The exception occurs during the Sandbian $\mathrm{Sa} 2$ where a pronounced decline in richness was caused by a falling origination rate rather than by elevated extinction.

\section{Stable carbon isotope $\left(\delta^{13} \mathrm{C}\right)$ anomalies}

A contrast between an Ordovician and a Silurian pattern similar to that in graptoloid evolution is seen in the global generalized $\delta^{13} \mathrm{C}_{\text {carb }}$ curve (Fig. 3; Bergström et al. 2009; Cramer et al. 2011; Saltzman \& Thomas, 2012). For more detail we show the curve of Ainsaar et al. (2010) based on the Baltic sequence, the Kaljo $\&$ Martma (2011) curve of the Mirny Creek sequence, Russia and a composite curve based on the Gotland Silurian succession (Fig. 4). The Silurian has been described as a time of extreme instability in the global carbon cycle (Munnecke et al. 2003, 2010; Cramer et al. 2010, 2011) and contrasts with the much more subdued excursions through most of the Ordovician. Further, the transition from an Ordovician to a Silurian pattern takes place during the Katian (Saltzman \& Young, 2005), as with the graptolites. Positive isotopic excursions in the Hirnantian, late Aeronian (Ae3), early Telychian (Te2), Sheinwoodian (Sh1-2), Homerian (Ho2-3) and Ludfordian (Lu1-2) all lie at times of depressed or falling graptoloid species richness, most also at times of elevated extinction rate (Figs 3, 4; Loydell, 2007). The Sheinwoodian event has been studied intensively (Munnecke et al. 2003; Cramer et al. 2010); conodonts, trilobites, brachiopods, corals and ostracods were exterminated in successive waves of extinction in the Baltic carbonate platform (Ireviken Event) and globally during the latest Telychian (Te5), immediately preceding the onset of both the isotope excursion and the graptolite extinction event (Munnecke et al. 2010) or during the graptolite extinction event itself (Loydell et al. 2003; Loydell, 2007).

In high resolution (Fig. 4), the extinction of graptolite species can be seen to coincide precisely with the positive isotope excursion during the early Sheinwoodian. There is a similar correlation during the Hirnantian, but here the duration of the extinction event is somewhat longer than that of the isotope event. There is an ongoing debate on the precise correlation of the Hirnantian $\delta^{13} \mathrm{C}_{\text {carb }}$ excursion (HICE) and graptolite biostratigraphy because sections with good biostratigraphic control such as Dob's Linn (Scotland) and the Wangjiawan North section (China) do not contain enough carbonate for $\delta^{13} \mathrm{C}_{\text {carb }}$ measurements (Underwood et al. 1997; Chen et al. 2006), whereas carbonate-rich successions such as on Anticosti or in S. Sweden are usually very sparsely populated with diagnostic graptolites (Melchin \& Holmden, 2006; Melchin, 2008; Ainsaar et al. 2010; Bergström et al. 2012). There are a few exceptions however, such as the Vinini Creek section in central Nevada (Finney et al. 1999), the Mirny Creek section in SE Russia (Kaljo \& Martma, 2011) and the Honghuayuan and Daijiagou sections in S. China (Munnecke et al. 2011). The main question is whether the maximum $\delta^{13} \mathrm{C}$ values are correlated with the extraordinarius or with the persculptus zone. Both the Vinini Creek and the Mirny sections show the maximum values clearly positioned within the persculptus zone. At Dob's Linn, the stratotype for the Ordovician-Silurian boundary, the Hirnantian $\delta^{13} \mathrm{C}$ peak measured from organic material, is recorded from strata containing both Metabolograptus extraordinarius and Metabolograptus persculptus and thus belongs to the lower $M$. persculptus zone (Kaljo et al. 2008; Delabroye \& Vecoli, 2010). In $\mathrm{S}$. China, the maximum values are reported from strata assigned to the $M$. extraordinarius zone (Munnecke et al. 2011). However, as M. persculptus has not been found in these sections, a position of the $\delta^{13} \mathrm{C}$ peak within the lower M. persculptus zone cannot be excluded.

During the Homerian (Ho2-3), two maxima in the isotope curve align with two graptolite extinction events, but a larger extinction event in the preceding Hol (see review in Cramer et al. 2012) has no matching isotopic event (Fig. 4d). The big isotopic excursion during the Ludfordian (Samtleben et al. 1996, 2000; Jeppsson \& Aldridge, 2000; Jeppsson et al. 2007; Kaljo et al. 2007; Kozlowski \& Munnecke, 2010; Fig. 3) aligns with sharply falling richness. Many of the strong K-Silurian carbon isotope excursions are also associated with extinction events in the shallow marine carbonate facies and with positive shifts in the $\delta^{18} \mathrm{O}$ isotope ratio; however the causes of these correlations are uncertain (see Munnecke et al. $(2003,2010)$ for a summary).

There are exceptions to the general match of positive isotope excursions with richness depletions and extinction rate peaks. The broad positive isotope deflections in the middle Darriwilian (MDICE) and Aeronian (Ae1) overlap times of high species richness. In the Tremadocian ( $\operatorname{Tr} 2, R$. manitouensis zone) a small but sharp positive carbon isotopic event aligns with increasing graptoloid species richness (Buggisch et al. 2003). With the possible exception of the Darriwilian Dw3 (Turner et al. 2012), the much lower magnitude of the $\mathrm{pK}$-Ordovician positive isotope excursions and the fact that three of them (marked by lightly shaded bands in Fig. 3 and by $\mathrm{c}^{-}$in Fig. 4c) lack a corresponding diversity depletion or extinction rate peak suggest that their generating mechanism may be quite different from those of the K-Silurian. Major extinction peaks at the Sheinwoodian-Homerian boundary and the 
Pridoli (Pr1-Pr2 boundary) have no matching isotope excursion.

Statistical testing of the cross-correlations shows a complex pattern, consistent whether using $0.25 \mathrm{Ma}$ or $0.5 \mathrm{Ma}$ time bins. The $0.25 \mathrm{Ma}$ bin results are quoted here. In the K-Silurian, detrended richness correlates negatively with $\delta^{13} \mathrm{C}_{\text {carb }}$ (Pearson's $R=-0.235, p=$ 0.021 with a $0.5 \mathrm{Ma}$ lag), consistent with the pattern described above. In the pK-Ordovician however, after the Floian expansion, richness correlates positively with $\delta^{13} \mathrm{C}_{\text {carb }}(R=0.340, p<0.001$ with a $0.25 \mathrm{Ma}$ lag). Further, although many of the extinction rate peaks coincide closely with positive isotopic excursions, the overall extinction rate itself does not correlate significantly with carbon isotope ratio in either the Ordovician or Silurian. The same applies for the origination rate.

The general coincidence of major positive isotopic excursions with graptoloid depletions in richness in the K-Silurian is therefore supported and, as both the carbon isotopic composition and graptoloid ecology are intimately linked to oceanic geochemistry, circulation, bio-productivity, sea-level-induced carbonate weathering cycles and surface water temperature, this coincidence suggests a common environmental cause.

\section{The Katian-Hirnantian depletion in richness}

The spectacular decline in graptoloid species richness during the late Katian and Hirnantian is seen to be a monotonic event and can be dated precisely at 448$446 \mathrm{Ma}$ (Fig. 4). Our data suggest that the crisis was a short-lived event. If we take the widest view (from the beginning of the decline to the return to maximum richness in the late Aeronian), it lasted $8 \mathrm{Ma}$. If we take the time from average Katian richness levels before the event to average Rhuddanian-Aeronian levels after the event, it was only $3 \mathrm{Ma}$ (Fig. 4). In high resolution (Fig. 4e), we can see that the extinction event alone was only 1.3 Ma. This may be why the Hirnantian extinction does not show prominently in some analyses using a coarser timescale (e.g. Alroy, 2008).

The drop in richness was driven initially during the late Katian by rising extinction rate accompanied by a drop in the origination rate and subsequently in the Hirnantian by the high rate of extinction alone (Fig. 4b). However, whereas species richness declined in a single step, the high resolution extinction rate curves (Fig. 2b, c) show a distinct early peak in the early $\mathrm{Ka} 4$ and higher multiple peaks in the Hirnantian. The per million year rate of extinction was higher in the Katian than in the Hirnantian (Fig. 5), and many more graptoloid species were extinguished in the Katian than in the Hirnantian (Fig. 4a).

In the later part of the Ordovician, the Graptoloidea comprised two major high-level clades, the Diplograptina and the Neograptina (Melchin et al. 2011). In the late Katian (P. pacificus and pre-pacificus zones) species richness reached a peak of 86 at $447.8 \mathrm{Ma}$,

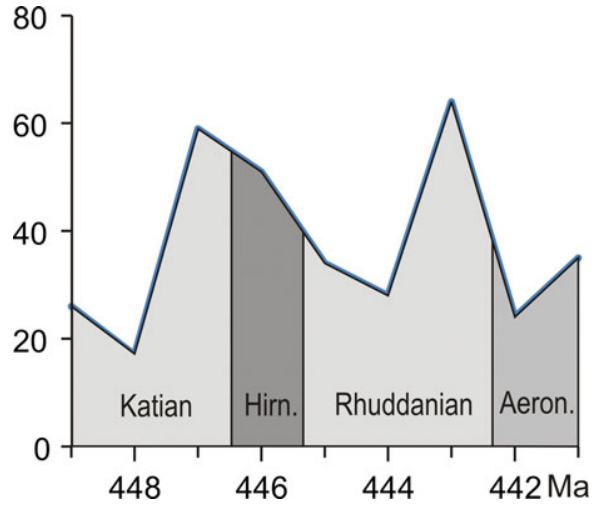

Figure 5. (Colour online) The number of species going extinct each million years ( $y$-axis) peaked in the late Katian and again in the Rhuddanian. $X$-axis is age in Ma.

with the expansion of the Diplograptina. As a result of the subsequent depletion in richness, standing species richness dropped to 20 in the Hirnantian (445.82 Ma), a loss of $77 \%$ of species in $2 \mathrm{Ma}$ (see also Melchin \& Mitchell, 1991; Chen et al. 2005). The entire Diplograptina were extirpated, including the familylevel groups Diplograptidae, Climacograptoidea, Dicranograptoidea as well as the Lasiograptidae, resulting in the near extinction of the clade and a major resetting of the diversity pattern and evolutionary history of graptoloids (Melchin \& Mitchell, 1991; Chen et al. 2005; Finney et al. 2007; Bapst et al. 2012; Melchin et al. 2011; Sadler et al. 2011; Štorch et al. 2011). In high resolution (Fig. 4e), the global graptoloid extinction rate was significantly elevated for $c .1 .3 \mathrm{Ma}$ and shows at least two main peaks in the Hirnantian. Two main episodes were found by Chen et al. (2005) in the Yangtze Platform sections where the event was estimated to have lasted $0.6-0.9 \mathrm{Ma}$. A two-strike extinction episode during the Hirnantian is also widely recognized in some benthic fossil groups such as brachiopods (Brenchley et al. 1995; Rasmussen \& Harper, 2011).

\section{The Llandovery recovery}

Minimum richness was very short lived. The surviving high-level clade, the Neograptina (represented by the Normalograptidae and the Retiolitoidea) which for the previous $20 \mathrm{Ma}$ had remained at relatively low richness, suddenly began to expand, creating a spike in the origination rate during the late Hirnantian. The diversification of the normalograptids followed their re-invasion of low palaeo-latitude regions (Goldman et al. 2011). Species richness immediately began to rise during Aeronian time, recovering to Ordovician peak levels within $5 \mathrm{Ma}$. The Rhuddanian-Aeronian recovery, although initiated by a peak in the origination rate, was however maintained by a complex interplay of origination and extinction rates. Both rates rose and fell sharply in lockstep in several cycles, with the balance in favour of origination (Fig. 4b). As a result of this strong correlation between the two rate curves, 
Table 2. Comparison of Floian radiation with Llandovery recovery

\begin{tabular}{lrr}
\hline & $\begin{array}{c}\text { Floian } \\
\text { radiation }\end{array}$ & $\begin{array}{c}\text { Llandovery } \\
\text { recovery }\end{array}$ \\
\hline Age base (Ma) & 478 & 446 \\
Age top (Ma) & 473 & 441 \\
Duration (Ma) & 5 & 5 \\
Diversity at base & 22 & 25 \\
Diversity at top & 78 & 69 \\
Diversity increase & 56 & 44 \\
Originating species & 149 & 229 \\
Extinguishing species & 93 & 185 \\
Mean origination rate $\bar{p}$ & 0.623 & 1.043 \\
Maximum origination rate $p_{\max }$ & 1.613 & 3.063 \\
Mean extinction rate $\bar{q}$ & 0.349 & 1.481 \\
Maximum extinction rate $q_{\max }$ & 0.863 & 1.913 \\
Median longevity (Ma) & 1.806 & 0.863 \\
\hline
\end{tabular}

species richness continued to progressively rise through the Rhuddanian and Aeronian despite several sharp extinction events, particularly the Rh2-3 event. Our data indicate a rapid response time; the lag between an extinction rate rise and the ensuing origination increase during the recovery phase (through the Rhuddanian and Aeronian) is less than $0.1 \mathrm{Ma}$ and is $c .0 .5 \mathrm{Ma}$ in the Hirnantian (Fig. 4a, b).

The recovery was driven by a dramatic expansion of the Neograptina. Melchin et al. (2012) recognized three phases in the radiation of the Neograptina: an early radiation at the base of the Hirnantian; a second phase starting in the post-glacial latest Hirnantian; and a third phase during the middle Rhuddanian. The neograptine family-level clades Normalograptidae and Neodiplograptidae expanded rapidly, followed by the Retiolitidae and Monograptoidea which began their primary diversification in the third phase.

It is instructive to compare the rate dynamics behind the Llandovery recovery with those of the Floian radiation (for purposes of comparison here taken as 446-441 Ma and 478-473 Ma, respectively). Although the Llandovery recovery records a smaller increase in standing species richness ( 44 species versus 56 species in the Floian; Table 2), it involved the generation of many more new species; 229 species appeared during the Llandovery recovery with a mean origination rate of 1.043 , and 149 species appeared during the radiation of the graptoloid clade during the Floian with a mean origination rate of 0.623 . It is the much lower extinction rate during the Floian $(0.349$ versus 0.863 in the Llandovery) that explains this apparent contradiction, resulting in longer durations of Floian species. Median species duration in the Floian radiation is $1.806 \mathrm{Ma}$ whereas median duration in the Llandovery recovery is $0.863 \mathrm{Ma}$.

The ecological factors involved in the endOrdovician extinction and Llandovery recovery of the graptoloid clade have been discussed by Melchin \& Mitchell (1991), Chen et al. (2005) and Finney et al. (2007). Bapst et al. (2012) found that the rebound in morphologic disparity lagged the rebound in species richness during the early recovery phase in the Hirnantian, and they concluded that unknown and non-ecological factors were controlling this phase of the recovery.

\section{Graptoloid extinctions and global climate}

In the past two decades the picture of the Ordovician and Silurian climatic development has changed significantly. Oxygen isotope data indicate a long phase of cooling during the Ordovician, with a climax in the Hirnantian (Trotter et al. 2008). There is however still no agreement on the tropical seasurface temperatures (Pucéat et al. 2010; see review in Munnecke et al. 2010) with a wide range of interpretations, for example, from $>10{ }^{\circ} \mathrm{C}$ warmer than today's oceans (Came et al. 2007) to $c .10{ }^{\circ} \mathrm{C}$ cooler than today for the early Silurian (Giles, 2012). Similarly, there is no general agreement on Silurian eustacy (Munnecke et al. 2010). The amplitudes of the $\delta^{18} \mathrm{O}$ and $\delta^{13} \mathrm{C}$ excursions are extremely high compared to the Mezozoic and Cenozoic, hampering the application of Cenozoic models. Nevertheless, most authors agree that the pronounced stable carbon and oxygen isotope fluctuations are not a diagenetic artefact but reflect strong environmental changes. The carbonate carbon isotope record is linked directly to the biosphere and to the global carbon cycle (Saltzman \& Thomas, 2012). According to Saltzman (2005), the pre-Katian time of comparatively stable $\delta^{13} \mathrm{C}$ values (Fig. 3) reflects negative feedbacks on bioproductivity in a warm ocean with a low nitrogren:phosphorus ratio in which anoxia led to increased denitrification. During the Sandbian, this system changed to a cooler welloxygenated phosphorus-limited ocean, which lasted until the Early Devonian.

Graptoloids are inferred to have been a major component of the Early Palaeozoic macrozooplankton (Bulman, 1964; Rickards, 1975; Cooper et al. 2012). The habitat of the planktic graptoloids was intimately linked with ocean circulation, density stratification, upwelling systems, nutrient flux and temperature gradients, most probably through their inferred dependency on the marine microphytoplankton and bacterioplankton as a food resource (Rigby, 1991; Cooper et al. 2012). These oceanic parameters are in turn closely linked with global climatic regime. It is therefore not surprising that the broad graptolite macroevolutionary pattern matches the broad global climatic pattern, particularly the contrast between the pK-Ordovician and K-Silurian intervals. Our graptoloid evolutionary rates provide strong supporting evidence that this transition took place during the Katian (Saltzman \& Young, 2005; Munnecke et al. 2010; Finnegan et al. 2011).

The late Katian-Hirnantian graptoloid extinction, diversity depletion and mass faunal turnover is clearly part of the global Hirnantian Mass Extinction associated with climatic deterioration and polar icesheet growth (Ghienne, 2003; Le Heron, 2007), and recognized as one of the 'big five' mass extinctions during the Phanerozoic (Sepkoski, 1995; Bambach 
et al. 2004). The six sharp graptoloid extinction events during the Silurian are of comparable intensity to that of the late Katian - Hirnantian. They suggest that the extreme environmental conditions that brought about the Katian-Hirnantian event recurred through the Silurian. Continental glacial events have been recognized at several levels at least during the early Silurian (Díaz-Martínez \& Grahn, 2007; Loydell, 2007), and the oxygen isotopic evidence suggests strong fluctuations in sea-surface temperatures during the K-Silurian (summarized in Munnecke et al. 2010; Finnegan et al. 2011). The graptolite evolutionary rates suggest a means of fine-tuning these events.

However, the precise correlation of an extinction event or diversity decline with its accompanying carbon isotope excursion is not straightforward. Not all extinction events have matching isotope excursions; of those that do, not all align consistently. It has been suggested that isotopic, biotic and climatic events and sea-level change follow a cascading cause-and-effect cycle rather than a simultaneous happening (Samtleben et al. 2000; Cramer \& Munnecke, 2008; Cramer et al. 2010; Munnecke et al. 2012). Further, it is likely that biotic interactions, such as reduced competition for food resources and niche space following environmentally induced population crashes, also influence diversity changes, especially in the K-Silurian.

The cross-correlations discussed suggest that environmental parameters, as represented by $\delta^{13} \mathrm{C}_{\text {carb }}$, are linked to diversity, as represented by graptoloid species richness, but that this operates positively in the pK-Ordovician and negatively in the K-Silurian. The link between extinction rate and environmental change is less easy to interpret. Many, but not all, of the major extinction rate peaks in the K-Silurian align with isotopic events, but the overall extinction rate does not correlate significantly with $\delta^{13} \mathrm{C}$. The question needs further investigation. Regardless, graptoloid evolutionary dynamics appear to exhibit a similar sensitivity to climatically forced global changes in ocean circulation and chemistry as planktonic foraminifera in the Mesozoic and Cenozoic (Peters et al. 2013). We predict that climatically forced, sharp environmental perturbations such as glacio-eustatic events (Calner, 2008) will be found at, or close to, the levels of those graptoloid extinction events associated with diversity declines and positive carbon isotope excursions.

\section{Conclusions}

For much of the pre-Katian Ordovician, graptoloid evolutionary rate excursions were relatively subdued and, except for the Darriwilian (Dw3), the extinction rate was probably close to background level. Species richness is positively correlated with $\delta^{13} \mathrm{C}_{\text {carb }}$. During the Late Ordovician and Silurian however, extinction rate was both higher and more volatile with recurring sharp peaks and sharp diversity drops which are interpreted as responses to environmental perturbations. Throughout the history of the graptoloid clade, all major depletions in richness were generated by elevated extinction rates, except for that of the Sandbian $\mathrm{Sa} 2$ where a decline was generated by a lowered origination rate.

The correlation between graptoloid diversification history and carbon isotope excursions suggest that graptolites can provide a sensitive proxy for physical, geochemical and biological changes related to global change in the marine environment in the same way as planktic microfossils in the Cenozoic. With the exception of a low-amplitude event in the Darriwilian, the Ordovician (from the Floian to the Katian, $30 \mathrm{Ma}$ ) emerges as an interval of relative environmental, isotopic and evolutionary stability, in contrast to the late Katian - Pridoli (30 Ma) which was an interval of extreme volatility in isotopic and evolutionary behaviour.

Acknowledgements. We thank Brad Cramer for discussion and for supplying a rescaled $\delta^{13} \mathrm{C}$ curve for the Silurian. Mike Melchin, Brad Cramer, Jan Zalasiewiscz and an anonymous reviewer reviewed the MS at various stages in its production and supplied constructive suggestions. This work was supported by the DFG (German Research Foundation; AM, grant number Mu 2352/3). Development of the CONOP software has been supported by grants from the National Science Foundation, most recently EAR 0518939. This manuscript is a contribution to IGCP 591: The Early to Middle Palaeozoic Revolution.

\section{References}

AinsaAR, L., Kaljo, D., MARTMa, T., MeIdla, T., MäNNIK, P., NõlvaK, J. \& TINN, O. 2010. Middle and Upper Ordovician carbon isotope chemostratigraphy in Baltoscandia: a correlation standard and clues to environmental history. Palaeogeography, Palaeoclimatology, Palaeoecology 294, 189-201.

ALROY, J. 2008. Dynamics of origination and extinction in the marine fossil record. Proceedings of the National Academy of Sciences, USA 105, 11536-42.

ALROY, J. 2010. Fair sampling of taxonomic richness and unbiased estimation of origination and extinction rates. In Quantitative Methods in Paleobiology, Paleontological Society Short Course, October 30th 2010 (eds J. Alroy \& G. Hunt), pp. 55-80. Paleontology Society Papers.

BAMBACH, R. K., KNOLl, A. H. \& WANG, S. C. 2004. Origination, extinction, and mass depletions of marine diversity. Paleobiology 30(4), 522-42.

BAPST, D. W., Melchin, M. J., SHeEts, H. D. \& Mitchell, C. E. 2012. Graptoloid diversity and disparity became decoupled during the Ordovician mass extinction. Proceedings of the National Academy of Sciences 109(9), 3428-33.

Bergström, S. M., Chen, X., Gutéirrez-Marco, J. C. \& DRONOV, A. 2009. The new chronostratigraphic classification of the Ordovician System and its relations to major regional series and stages and to $\delta^{13} \mathrm{C}$ chemostratigraphy. Lethaia 42, 97-107.

Bergström, S. M., Lehnert, O., CAlner, M. \& JOACHIMSKI, M. M. 2012. A new upper Middle Ordovician-Lower Silurian drillcore standard succession from Borenshult in Östergötland, southern Sweden: Significance of $\delta^{13} \mathrm{C}$ chemostratigraphy. GFF 134(1), 39-63. 
BICKERT, T. 2006. Influence of geochemical processes on stable isotope distribution in marine sediments, In Marine Geochemistry (eds H. D. Schulz \& M. Zabel), pp. 339-69, 2nd edition, Springer, Berlin.

Brenchley, P. J., Carden, G. A. F. \& Marshall, J. D. 1995. Environmental changes associated with the 'First Strike' of the Late Ordovician mass extinction. Modern Geology 50, 69-82.

Buggisch, W., Keller, M. \& Lehnert, O. 2003. Carbon isotope record of Late Cambrian to Early Ordovician carbonates of the Argentine Precordillera. Palaeogeography, Palaeoclimatology, Palaeoecology 195, 357-73.

Bulman, O. M. B. 1964. Lower Palaeozoic plankton [presidential address]. Quarterly Journal of the Geological Society of London 120, Part 4(480), 455-76.

CALNER, M. 2008. Silurian global events: at the tipping point of climate change. In Mass Extinctions (ed A. M. T. Elewa), pp. 21-58, Springer-Verlag, Heidelberg.

CAME, R. E., EILER, J. M., VEIZER, J., AZMY, K., BRAND, U. \& WeIDMAn, C. R. 2007. Coupling of surface temperatures and atmospheric $\mathrm{CO}_{2}$ concentrations during the Palaeozoic era. Nature 449, 198-201.

Chen, X., Melchin, M. J., Sheets, H. D., Mitchell, C. E. \& FAN, J.-X. 2005. Patterns and processes of latest Ordovician graptolite extinction and recovery based on the data from South China. Journal of Paleontology 79(5), 842-61.

Chen, X., Rong, J. Y., Fan, J. X., Zhan, R. B., Mitchell, C. E., Harper, D. A. T., Melchin, M. J., Peng, P., FINNEY, S. C. \& WANG, X. F. 2006. The global boundary stratotype section and point (GSSP) for the base of the Hirnantian Stage (the uppermost of the Ordovician System). Episodes 29, 183-96.

CoOper, R., Rigby, S., LOydell, D. K. \& BAtes, D. E. B. 2012. Palaeoecology of the Graptoloidea. Proceedings of the Yorkshire Geological Society 112, 23-41.

COOPER, R. A. \& SADler, P. M. 2012. The Ordovician Period. With a contribution by F. M. Gradstein \& O. Hammer. In The Geologic Time Scale 2012 (eds F. M. Gradstein, J. G. Ogg, M. Schmitz \& G. Ogg), pp. 489524, Elsevier.

Cramer, B. D., Brett, C. E., Melchin, M.J., MänNiK, P., Kleffner, M., Mclaughlan, P. I., Loydell, D., Munnecke, A., Jeppsson, L., Corradini, C., BRUnton, F. R. \& SAltZMAN, M. R. 2011. Revised correlation of Silurian provincial series of north America with global regional chronostratigraphic units and $\delta^{13} C_{\text {carb }}$ chemostratigraphy. Lethaia 44, 185-202.

Cramer, B. D., CONDON, D. J., SÖDERlund, U., MARShall, C., Worton, G. J., Thomas, A. T., Calner, M., Ray, D. C., Perrier, V., Boomer, I., PAtchett, P. J. \& JEPPSSON, L. 2012. U-Pb (zircon) age constraints on the timing and duration of Wenlock (Silurian) paleocommunity collapse and recovery during the 'Big Crisis'. Geological Society of America Bulletin 124, 1841-57.

Cramer, B. D., Loydell, D. K., Samtleben, C., Munnecke, A., Kaljo, D., MänniK, P., Martma, T., Jeppsson, L., KlefFner, M. A., BARrick, J. E., Johnson, C. A., EMSBO, P., JoAChimski, M. M., Bickert, T. \& SAltzMan, M. R. 2010. Testing the limits of Paleozoic chronostratigraphic correlation via high-resolution $(<500,000 \mathrm{yrs})$ integrated conodont, graptolite, and carbon isotope $\left(\delta^{13} \mathrm{C}_{\text {carb }}\right)$ biochemostratigraphy across the Llandovery-Wenlock boundary: is a unified Phanerozoic timescale achievable? Geological Society of America Bulletin 122, $1700-16$.
Cramer, B. D. \& Munnecke, A. 2008. Early Silurian positive $\delta^{13} \mathrm{C}$ excursions and their relationship to glaciations, sea-level changes and extinction events: discussion. Geological Journal 43, 517-19.

Cramer, B. D. \& SAltzman, M. R. 2007. Early Silurian paired $\delta^{13} \mathrm{C}_{\text {carb }}$ and $\delta^{13} \mathrm{C}_{\text {org }}$ analyses from the Midcontinent of North America: implications for paleoceanography and paleoclimate. Palaeogeography, Palaeoclimatology, Palaeooceanology 256, 195-203.

Delabroye, A. \& Vecoli, M. 2010. The end-Ordovician glaciation and the Hirnantian Stage: a global review and questions about Late Ordovician event stratigraphy. Earth-Science Reviews 98, 269-82.

DÍAZ-MARTÍNEZ, E. \& GRAHN, Y. 2007. Early Silurian glaciation along the western margin of Gondwana (Peru, Bolivia and northern Argentina): palaeogeographic and geodynamic setting. Palaeogeography, Palaeoclimatology, Palaeoecology 245, 62-81.

Finnegan, S., Bergmann, K., Eiler, J. M., Jones, D. S., Fike, D. A., Eisenman, I., Hughes, N. C., Tripati, A. K. \& WoODWARD, W. F. 2011. The magnitude and duration of Late Ordovician-Early Silurian glaciation. Science 331, 903-6.

FINNEY, S. C. \& BERRY, W. B. N. 1997. New perspectives on graptolite distributions and their use as indicators of platform margin dynamics. Geology 25(10), 919-22.

FinNeY, S. C., BerRY, W. B. N. \& COOPER, J. D. 2007. The influence of denitrifying seawater on graptolite extinction and diversification during the Hirnantian (latest Ordovician) mass extinction event. Lethaia 40, 281-91.

FINNEY, S. C., BERRY, W. B. N., COOPER, J. D., RIPPERDAN, R. L., Sweet, W.C., Jacobson, S. R., Soufiane, A., ACHAB, A. \& NoBle, P. J. 1999. Late Ordovician mass extinction: a new perspective from stratigraphic sections in central Nevada. Geology 27, 215-18.

FoOTE, M. 1994. Temporal variation in extinction risk and temporal scaling of exctinction metrics. Paleobiology 20(4), 424-44.

Foote, M. 2000. Origination and extinction components of taxonomic diversity: general problems. Paleobiology 26(suppl.), 74-102.

Foote, M. \& Miller, A. I. 2007. Principles of Paleontology. W H Freeman \& Co., New York, 354 pp.

GHIENNE, J. F. 2003. Late Ordovician sedimentary environments, glacial cycles, and post-glacial transgression in the Taoudeni Basin, West Africa. Palaeogeography, Palaeoclimatology, Palaeoecology 189, 11745.

GILES, P. S. 2012. Low-latitude Ordovician to Triassic brachiopod habitat temperatures (BHTs) determined from $\delta^{18} \mathrm{O}_{\text {(brachiopod calcite) }}$ : a cold hard look at ice-house tropical oceans. Palaeogeography, Palaeoclimatology, Palaeoecology 317/813 25-431.

Goldman, D., Mitchell, W. I., Melchin, M. J., FAN, J.X., WU, S.-Y. \& SHEETS, H. D. 2011. Biogeography and mass extinction: extirpation and re-invasion of Normalograptus species (Graptolithina) in the Late Ordovician paleotropics. Proceedings of the Yorkshire Geological Society 58(4), 227-46.

Gradstein, F. M, OGG, J. G., Schmitz, M. D., OGG, G. M. et al. 2012. The Geologic Time Scale 2012. Elsevier, $1176 \mathrm{pp}$.

Gutiérrez-Marco, J. C., Lenz, A. C., Robardet, M. \& PICARRA, J. M.1996. Wenlock-Ludlow graptolite biostratigraphy and extinction: A reassessment from the southwestern Iberian Peninsula (Spain and Portugal). Canadian Journal of Earth Sciences 33(5), 656-63. 
Hayes, J. M., Strauss, H. \& Kaufman, A. J. 1999. The abundance of ${ }^{13} \mathrm{C}$ in marine organic matter and isotopic fractionation in the global biogeochemical cycle of carbon during the past $800 \mathrm{Ma}$. Chemical Geology 161, $103-25$.

Hayward, B. W., Ashwag, T. S., KolodzieJ, A., Crundwell, M. P., StePh, S., ScotT, G. H., NeIl, H. L., Bostock, H. C., Carter, L. \& Grenfell, H. R. 2012. Planktic foraminifera-based sea-surface temperature record in the Tasman Sea and history of the Subtropical Front around New Zealand, over the last one million years. Marine Micropaleontology 82-3, 13-27.

Hingaga, K. R., Arthur, M. A., Pilson, M. E. Q. \& WhITAKER, D. 1994. Carbon isotope fractionation by marine phytoplankton in culture: the effects of $\mathrm{CO}_{2}$ concentration, $p \mathrm{H}$, temperature, and species. Global Biogeochemical Cycles 8, 91-102.

JAEGER, H. 1991. Neue Standard-Graptolithenzonenfolge nach der 'Großen Krise' an der Wenlock/LudlowGrenze (Silur). Neues Jahrbuch für Geologie und Paläontologie, Abhandlungen 182(3), 303-54.

JEPPSSON, L. 1997. The anatomy of the mid-early Silurian Ireviken Event and a scenario for P-S events. In Paleontological Events: Stratigraphic, Ecologic, and Evolutionary Implications (eds C. E. Brett \& G. C. Baird), pp. 451-92, Columbia University Press, New York.

JEPPSSON, L. \& ALDRIDGE, R. J. 2000. Ludlow (late Silurian) oceanic episodes and events. Journal of the Geological Society, London 157, 1137-48.

Jeppsson, L., Talent, J. A., Mawson, R., Simpson, A. J., Andrew, A. S., Calner, M., Whitford, D. J., Trotter, J. A., SANDSTRÖM, O. \& CAlCON, H.J. 2007. High-resolution Late Silurian correlations between Gotland, Sweden, and the Broken River region, NE Australia: lithologies, conodonts and isotopes. $\mathrm{Pa}$ laeogeography, Palaeoclimatology, Palaeoecology 245, 115-37.

Kaljo, D., Boucot, A. J., Corfield, R.M., Le Herisse, A., KOREN', T.N., KŘİ̌̌, J., MÄNNIK, P., MÄRsS, T., Nestor, V., Shaver, R. H., Siveter, D. J. \& ViIRA, V. 1995. Silurian bioevents. In Global Events and Event Stratigraphy in the Phanerozoic (ed O. H. Walliser), pp. 173-224, Springer-Verlag, Berlin.

Kaljo, D., Grytsenko, V., Martma, T. \& Motus, M. A. 2007. Three global carbon isotope shifts in the Silurian of Podolia (Ukraine): stratigraphical implications. Estonian Journal of Earth Sciences 56, 205-220.

Kaljo, D., Hints, L., MÄNNIK, P. \& NÕLVAK, J. 2008. The succession of Hirnantian events based on data from Baltica: brachiopods, chitinozoans, conodonts, and carbon isotopes. Estonian Journal of Earth Sciences 57(4), 197-218.

KAlJO, D. \& MarTMA, T. 2011. Carbon isotope trend in the Mirny Creek area, NE Russia, its specific features and possible implications of the uppermost Ordovician stratigraphy. In Ordovician of the World (eds J. C. Gutiérrez-Marco, I. Rábano \& D. García-Bellido), pp. 267-73, Cuadernos del Museo Geominero, 14, Instituto Geológico y Minero de España, Madrid.

Koren', T. N. 1987. Graptolite dynamics in Silurian and Devonian time. In Third International Graptolite Conference 'Palaeobiology and Geological Use of Graptolites', Reitzels Forlag Hans, Copenhagen, Denmark.

KOREN', T. N. 1991. The lundgreni extinction event in central Asia and its bearing on graptolite biochronology within the Homerian. Proceedings of the Estonian Academy of Sciences, Geology 40(2), 74-8.

KOREN', T. \& BJERRESKOV, M. 1999. The generative phase and the first radiation event in the early Silurian monograptid history. Palaeogeography, Palaeoclimatology, Palaeoecology 154, 3-9.

KozlowsKi, W. \& MUNNECKE, A. 2010. Stable carbon isotope development and sea-level changes during the Late Ludlow (Silurian) of the Lysogóry region (Rzepin section, Holy Cross Mountains, Poland). Facies 56, 61533.

LE HERON, D. P. 2007. Late Ordovician glacial record of the Anti-Atlas, Morocco. Sedimentary Geology 201, 93110.

LENZ, A. C. 1993. Late Wenlock-Ludlow (Silurian) graptolite extinction, evolution, and biostratigraphy: perspectives from Arctic Canada. Canadian Journal of Earth Sciences 30(3), 491-8.

LOYDELL, D. K. 1994. Early Telychian changes in graptoloid diversity and sea level. Geological Journal 29(4), 355 68.

LOYDELL, D. 2007. Early Silurian positive $\delta^{13} \mathrm{C}$ excursions and their relationship to glaciations, sea-level changes and extinction events. Geological Journal 42(5), 53146.

LOYDELL, D. K., MÄNNIK, P. \& NESTOR, V. 2003. Integrated biostratigraphy of the lower Silurian of the Aizpute-41 core, Latvia. Geological Magazine 140, 205-29.

Maletz, J., CARlucci, J. \& Mitchell, C. E. 2009. Graptoloid cladistics, taxonomy and phylogeny. Bulletin of Geosciences 84(1), 7-19.

MANDA, S., ŠTORCH, P., SlAVÍK, L., FrÝdA, J., KŘIŽ, J. \& TÁSARYOVÁ, Z. 2012. The graptolite, conodont and sedimentary record through the late Ludlow Kozlowskii Event (Silurian) in the shale-dominated succession of Bohemia. Geological Magazine 149(3), 507-31.

MELCHIN, M. J. 2008. Restudy of some Ordovician-Silurian boundary graptolites from Anticosti Island, Canada, and their biostratigraphic significance. Lethaia 41, 155-62.

Melchin, M. J. \& Holmden, C. 2006. Carbon isotope chemostratigraphy in Arctic Canada: sea-level forcing of carbonate platform weathering and implications for Hirnantian global correlation. Palaeogeography, Palaeoclimatology, Palaeoecology 234(2-4), 186200.

Melchin, M. J., Koren', T. N. \& ŠTORCH, P. 1998. Global diversity and survivorship patterns of Silurian Graptoloids. In Silurian Cycles: Linkages of Dynamic Stratigraphy with Atmospheric, Oceanic and Tectonic Changes (eds E. Landing \& M. E. Johnson), pp. 16582. New York State Museum Bulletin.

Melchin, M. J. \& Mitchell, C. E. 1991. Late Ordovician extinction in the Graptoloidea. In Advances in Ordovician Geology (eds C. R. Barnes \& S. H. Williams), pp. 143-56. Geological Survey of Canada, Ottawa.

Melchin, M. J., Mitchell, W. I., NACYK-CAMERON, A., FAN, J. X. \& LOXTON, J. 2011. Phylogeny and adaptive radiation of the Neograptina (graptoloida) during the Hirnantian mass extinction and Silurian recovery. Proceedings of the Yorkshire Geological Society 58(4), 281-309.

Melchin, M. J., SADler, P. M. \& Cramer, B. D. 2012. The Silurian Period. With contributions by R. Cooper, O. Hammer and F. M. Gradstein. In The Geological Time Scale 2012 (eds F. M. Gradstein, J. G. Ogg, M. Schmitz, G. Ogg et al.), pp. 525-59, Elsevier.

Mitchell, W. I., Goldman, D., Klosterman, S. L., MAletZ, J., Sherwin, L. \& Melchin, M. J. 2007. 
Phylogeny of the Diplograptoidea. Acta Palaeotologica Polonica 46(Suppl.), 332-9.

Munnecke, A., Calner, M., Harper, D. A. T. \& Servais, T. 2010. Ordovician and Silurian sea-water chemistry, sea level, and climate: a synopsis. Palaeogeography, Palaeoclimatology, Palaeoecology 296, 389-413.

MunNecke, A., Delabroye, A., Servais, T., VAndenbroucke, T. R. A. \& Vecoli, M. 2012. Systematic occurrences of malformed (teratological) acritarchs in the run-up of Early Palaeozoic $\delta^{13} \mathrm{C}$ isotope excursions. Palaeogeography, Palaeoclimatology, Palaeoecology 367-8, 137-46.

Munnecke, A., SAmtleben, C. \& Bickert, T. 2003. The Ireviken Event in the lower Silurian of Gotland, Sweden: relation to similar Palaeozoic and Proterozoic events. Palaeogeography, Palaeoclimatology, Palaeoecology 195(1-2), 99-124.

Munnecke, A., Zhang, Y., LiU, X. \& Cheng, J. 2011. Stable carbon isotope stratigraphy in the Ordovician of South China. Palaeogeography, Palaeoclimatology, Palaeoecology 307, 17-43.

Peters, S.E., Kelly, D.C. \& FraAss, A.J. 2013. Oceanographic controls on the diversity and extinction of planktonic foraminifera. Nature 493(7432), 398401.

PUCÉAT, E., JOACHIMSKI, M. M., BOUILlOUX, A., MONNA, F., Bonin, A., Motreuil, S., Morinière, P. \& HÉnARD, S. 2010. Revised phosphate-water fractionation equation reassessing paleotemperatures derived from biogenic apatite. Earth and Planetary Science Letters 298, 13542.

R Development Core TeAm. 2011. R: A Language and Environment for Statistical Computing. R Foundation for Statistical Computing, Vienna, Austria.

RASMussen, C. M. O. \& HARPER, D. A. T. 2011. Did the amalgamation of continents drive the end Ordovician mass extinctions? Palaeogeography, Palaeoclimatology, Palaeoecology 311(2), 48-62.

RAUP, D. M. 1985. Mathmematical models of cladogenesis. Paleobiology 11(1), 42-52.

RICKARDS, R. B. 1975. Palaeoecology of the Graptolithina, an extinct class of the phylum Hemichordata. Biological Reviews of the Cambridge Philosophical Society 50, 397-436.

RIGBY, S. 1991. Feeding strategies in graptoloids. Palaeontology 34(4), 797-815.

SADLER, P. M. 2004. Quantitative biostratigraphy: achieving finer resolution in global correlation. Annual Review of Earth and Planetary Sciences 32, 187-213.

SAdler, P. M. \& CoOPER, R. A. 2011. Graptoloid evolutionary rates: sharp contrast between Ordovician and Silurian. In Ordovician of the World. $11^{\text {th }}$ International Symposium on the Ordovician System (eds J.C. Gutiérrez-Marco, I. Rabano \& D. Garcia-Bellido), pp. 499-504, Insituto Geologico y Minero de Espana, Madrid.

SAdler, P. M., CoOper, R. A. \& Melchin, M. J. 2009. High-resolution, early Paleozoic (Ordovician-Silurian) timescales. Geological Society of America Bulletin 121(5/6), 887-906.

SAdler, P. M., CoOper, R. A. \& Melchin, M. J. 2011. Sequencing the graptolite clade: building a global diversity curve from local range-charts, regional composites and global time-lines. Proceedings of the Yorkshire Geological Society 58(4), 329-43.

SAltzMAN, M. R. 2005. Phosphorous, nitrogen, and the redox evolution of the Paleozoic oceans. Geology 33, 573-76.
Saltzman, M. R. \& Thomas, E. 2012. Carbon isotope stratigraphy. In The Geologic Time Scale 2012 (eds F. M. Gradstein, J. G. Ogg, M. D. Schmitz, G. M. Ogg et al.), pp. 207-32. Elsevier.

SAltZMAN, M. R. \& YounG, S. A. 2005. Long-lived glaciation in the Late Ordovician? Isotopic and sequencestratigraphic evidence from western Laurentia. Geology 33, 109-12.

Samtleben, C., Munnecke, A., Bickert, T. \& PÄtzold, J. 1996. The Silurian of Gotland (Sweden): facies interpretation based on stable isotopes in brachiopod shells. Geologische Rundschau 85, 278-92.

Samtleben, C., Munnecke, A. \& Bickert, T. 2000. Development of facies and $\mathrm{C} / \mathrm{O}$-isotopes in transects through the Ludlow of Gotland: evidence for global and local influences on a shallow-marine environment. Facies 43, 1-38.

SEPKOSKI, J. J. 1995. The Ordovician radiations: diversification and extinction shown by global genuslevel taxonomic data. In Ordovician Odyssey: Short Papers for the Seventh International Symposium on the Ordovician System (eds J. D. Cooper, M. L. Droser \& S. C. Finney), pp. 393-6, Pacific Section Society for Sedimentary Geology (SEPM), Fullerton, California.

Servais, T., Lehnert, O., Li, J., Mullins, G. L., MunNeCKe, A., NÜtzel, A. \& Vecoli, M. 2008. The Ordovician Biodiversification: revolution in the oceanic trophic chain. Lethaia 41(2), 99-109.

Servais, T., Owen, A. W., HARPer, D.A.T., KrÖger, B. \& MunNeCKE, A. 2010. The Great Ordovician Biodiversification Event (GOBE): the palaeoecological dimension. Palaeogeography, Palaeoclimatology, Palaeoecology 294, 99-119.

SHEEHAN, P. M. 2001. The Late Ordovician mass extinction. Annual Review of Earth and Planetary Sciences 29, 331-64.

ŠTORCH, P. 1994. Graptolite biostratigraphy of the Lower Silurian (Llandovery and Wenlock) of Bohemia. Geological Journal 29(2),137-65.

ŠTORCH, P. 1995. Biotic crises and post-crisis recoveries recorded by Silurian planktonic graptolite faunas of the Barrandian area (Czech Republic). Geolines 3, 5970.

Štorch, P., Mitchell, C. E., Finney, S. C. \& Melchin, M. J. 2011. Uppermost Ordovician (upper KatianHirnantian) graptolites of north-central Nevada, USA. Bulletin of Geosciences 86(2), 301-86.

Trotter, J. A., Williams, I. S., Barnes, C. R., LeCuyer, C. \& NiCOLL, R. S. 2008. Did cooling oceans trigger Ordovician biodiversification? Evidence from conodont thermometry. Science 321, 550-4.

Turner, B. R., Armstrong, H. A., Wilson, C. R. \& MAKHLOUF, I. M. 2012. High frequency eustatic sealevel changes during the Middle to Early Ordovician of Southern Jordan: indirect evidence for a Darriwilian Ice Age in Gondwana. Sedimentary Geology 251-2, 34 48.

Underwood, C. J., Crowley, S. F., Marshall, J. D. \& BRENCHLEY, P. J. 1997. High-resolution carbon isotope stratigraphy of the basal Silurian Stratotype (Dob's Linn, Scotland) and its global correlation. Journal of the Geological Society 154, 709-18.

URBANEK, A. 1993. Biotic crises in the history of Upper Silurian graptoloids: a palaeobiological model. Historical Biology 7, 29-50.

VANDENBRoucKe, T. R. A., ARMSTRONG, H. A., Williams, M., Sabbe, K., Zalasiewicz, J. A., NolvaK, J. \& VERNIERS, J. 2010. Epipelagic chitinozoan biotopes map 
a steep latitudinal temperature gradient for earliest Late Ordovician seas: implications for a cooling Late ordovician climate. Palaeogeography, Palaeoclimatology, Palaeoecology 294, 202-19.

Vecoli, M., Riboulleau, A. \& Versteegh, G. J. M. 2009. Palynology, organic geochemistry and carbon isotope analysis of a latest Ordovician through Silurian clastic succession from borehole Tt1, Ghadamis Basin, southern Tunisia, North Africa: palaeoenvironmental in- terpretation. Palaeogeography, Palaeoclimatology, $\mathrm{Pa}$ laeoecology 273, 378-94.

Webby, B. D., Droser, M. L. \& Paris, F. 2004. The Great Ordovician Biodiversification Event. Columbia University Press, 484 pp.

Zhang, T.-G., Trela, W., JiAng, S.-Y., Nielsen, J. K. \& SHEN, Y. 2011. Major oceanic redox condition change correlated with the rebound of marine animal diversity during the Late Ordovician. Geology 39 (7), 675-8. 